\title{
O DEVIR EM ÉDIPO-REI
}

\section{WILTON FRED CARDOSO DE OLIVEIRA}

\section{N T R O D U Ç ÃO}

\author{
A imaginação não é, como sugere a etimologia, a faculdade de \\ formar imagens da realidade; ela é a faculdade de formar \\ imagens \\ que ultrapassam a realidade, que cantam a realidade. É uma \\ faculdade de sobre-humanidade." \\ (p.XVI - O Direito de Sonhar)
}

Ao tomarmos a visão de Bachelard sobre a imaginação e sobre a arte, nela vemos o lastro de que necessitamos para iniciarmos o nosso trabalho.

Bachelard, ao dizer que a imaginação é um ato de sobre-humanidade, coloca a obra de Arte num plano inverso ao platônico. Ela passa a ser não mais a criação da criação, algo inferior por se tratar da recriação do Sensível, mas um acontecimento do Lógos. E se assim o é, é fruto da razão en-quanto primeira substância ou causa do mundo, é divina, consoante Heráclito. ( 2 p.601 Abbagnano)

Partindo-se desse pressuposto, a obra Edipo-Rei de Sófocles, antes de ser mero retrato da realidade sensível, é um lógos que encerra em si a problemática grega do DE-VIR, mudança que vai do Nada ao Ser e deste ao Nada. Sófocles, nesta obra, em 430 a.C, já consegue conciliar o problema posto por Heráclito de Éfeso (549? -475?) de que todas as coisas estão em constante mudança e movimento, bem como de Parmênides (515/510 - 435?) de que todas as coisas são imóveis e ingênitas. Ele antecipa a solução que Platão (429/427 - 348/347) conseguirá levar a cabo com a teoria do Mundo das Idéias e do Mundo Sensível, quase meio século depois.

Em seu drama EDIPO-REI, através das figuras de Laios e de Édipo, é trabalhada a questão grega da visão Circular de Mundo, bem como, a luta travada no pensamento antigo entre Sensível e Inteligível. O Mundo do Devir, passível apenas da DOXA e o mundo da EPISTEME já são delineados por Sófocles em sua literatura.

O problema edipiano é o problema da Verdade, o que lhe perturba a existência e fá-lo fugir de suas origens. Essa Verdade lhe é dada através do Oráculo de Delphos (aquele que vê), e diante desses olhos que viam aquilo que seus olhos não podiam ver, diante dessa visão de sobre-humanidade, tanto Laios quanto Édipo se curvam, visto que se via a Corrupção das coisas só podia ver através da visão da Mente, Lógos Atemporal Inteligível, Incorruptível que, depositário da Verdade, revelou-lhes que eles eram entes perecíveis, não eternos, posição essa que pretendiam ocupar. Laios tentou fugir à determinação do Lógos; Édipo ao seu vaticínio, e assaltado por essa angústia, este fugiu para sua "determinação" sem o saber. Na tentativa de evitar o DEVIR, tanto Laios quanto Édipo fizeram o devir.

Havia nesses personagens o medo do LOGOS, essa essência do destino difundida no universo e representada pelo Oráculo, o detentor do Destino, do Inteligível; e se assim o é, jamais poderia errar, conseqüentemente, tanto a vida de Laios, quanto a de Édipo passaram a ser determinadas por Ele. O que o Oráculo revelava passou a fazer parte dum ciclo que tinha que ser cumprido, para que se cumprisse a ordem do Universo. E é exatamente dessa ordem que os persona-gens tentam fugir, como se fosse possível fugir ao DEVIR. Mas se isso tentaram é porque desconheciam a sua própria essência, possuidora dum lógos que por si só seria capaz de ver-se. Entraram no Oráculo, com vistas depositadas no que está por detrás das coisas, sem se importar com a COISA que eram eles, daí ignorarem o dizer acima da entrada, no portal: 
início do pensamento filosófico, designa esse deixar falar as coisas sem lhes impor um sentido estranho, antes deixando que elas, manifestando-se, se imponham"

(p.32, 33-Filosofia Antiga - Severino).

Laios e Édipo não permitiram que esse Lógos se manifestasse; não buscaram conhecerem-se; não tinham em mente que a "vida, consoante Friederich Nietzche, (Fogo Grego p.2) se não examinada não merece ser vivida." É exatamente isso que eles não fizeram: desconheciam quem eram, não se preocuparam, no entanto, em saber donde vinham , uma vez que o passado não pode ser destruído e deve ser conhecido.

Nada determinava o Oráculo, apenas, consoante o próprio Heráclito: " ... o Senhor de Delfos não esclarece nem esconde, oferece signos" (p. 2 Fogo Grego), ofereceu-os aos personagens de Sófocles. Para esses, os signos oferecidos implicaram o abandono do Lógos Individual para dar lugar ao Lógos Universal; já nas mãos de Sófocles, esses signos se transformaram na representação da realidade, a qual se faz enquanto signo, não sujeita ao DEVIR. Sófocles parou seus personagens no tempo e no espaço; fez um corte na duração (bergsoniana)da realidade, para, num palco, propor, através de signos, o que é possível se ter do mundo da DOXA e da EPISTÉ-ME, através de Laios e de Édipo. O passado, na figura daquele, e o presente, na figura deste, chocaram-se querendo perpetuarem-se. Nenhum dos dois tinham consigo a consciência de que eram peremptórios, de que o homem é essencialmente devir. É esse o problema que nos cabe desenvolver e comprovar no decorrer desse trabalho. Para tanto, ater-nos-emos ao período filosófico que vai de Heráclito a Platão, para levar a cabo este nosso intento: O DEVIR EM ÉDIPO-REI.

O CENÁRIO:

\author{
(Um palácio, ao qual uma escadaria dá acesso, apresenta-se- \\ nos em cena. Junto a esta, uma estátua de APOLO, e, \\ próximo dela, um grupo de jovens, sentados ou de joelhos, \\ empunhando ramos de oliveira. O SACERDOTE de ZEUS \\ está no cen-tro, entre os jovens. ÉDIPO abandona agora 0 \\ palácio e vai descendo vagarosamente a escadaria, em \\ direção ao grupo.) \\ (p.115 Édipo Antigo)
}

Entremos na obra, mas adentremos lentamente, de forma vagarosa, atendo-nos a cada signo. Façamos o que impõe Umberto Eco para que o leitor adentre sua obra "O Nome da Rosa": "...se alguém quisesse entrar na abadia e viver nela sete dias, tinha que aceitar o seu ritmo" (p.36 - Pós-Escrito a O Nome da Rosa). É isso que temos que fazer ao lermos ÉDIPO-REI. Temos que vagarosamente esmiuçar as ruínas e buscar resgatar o Fogo Grego; isto é, aos poucos, lentamente, ir resgatando a centelha grega que há em nós e passarmos a pensar como um grego, através da intertextualidade grega. Somente assim poderemos compreender a obra em questão e seu Devir.

Para tanto, entremos em seu cenário. O Sacerdote, que de acordo com o Dicionário das Religiões (p.237) simboliza o "Pontifex Maximus", aquele que cuida do calendário, isto é, que controla o tempo, situa-se em meio a jovens que estão próximos da estátua de APOLO, o deus do Oráculo de Delfos, também chamado de deus da Luz, harmonizador dos contrários, o deus que vê. Notemos pois, que toda a problemática de Édipo surge exatamente pela questão do ver. O olhar para Sófocles é o causador da tragédia em que se transformou a vida de Édipo. Este precisa aprender a ver e a ser visto, precisa de "lux"; precisa contemplar a realidade, sair de sua "Caverna". Édipo colocava-se na posição de Zeus; caí-ra numa eterna atemporalidade, passara a ser o eterno "presente", a essência tebana, assim como Zeus, razão de todas as coisas.

Na obra Os Deuses Gregos, p. 126 (A Vida Cotidiana - Círculo do livro de Giulia Sissa e Marcel Detienne), os autores dão-nos Zeus, como uma consciência que não dormita, que não está sujeita ao tempo: " 
Édipo também sofrerá da mesma insônia, haja vista que se transforma nesse "Inteligível", usurpa um local que não Ihe pertence. Por isso o Sacerdote, de Zeus, não invoca o seu deus, mas a Édipo; porque, antes de ser Tebas, quem está sendo ultrajada, é o deus, é a Atemporalidade, pois este simboliza aquilo que se manifesta, bem como "o Senhor da Razão" consoante Junito (p.493 -dic.). Já, segundo Homero (verso II, XV, 192 - Junito p.494), é o deus que "...obteve por sorte o vasto céu com sua claridade e suas nuvens", simbolizando aquilo que está acima de; aquele que gera, princípio de todas as coisas, ou consoante Ésquilo (p.192 - Junito), o qual vai além de Homero na proclamação da soberania de Zeus:

\section{"Zeus é o éter, Zeus é a terra, Zeus é o céu. \\ Sim, Zeus é tudo quanto está acima de tudo." (Junito. p.498 -Dic.)}

Mesmo sendo assim classificado não se transforma no centro das invocações do sacerdote. Este pontífice, que se situa no meio, ou seja, no AXI-MUNDIS, detentor do tem-po, vai de encontro àquele que se coloca na posição da Verdade, ou de princípio gerador, visto que o ciclo grego precisa ser retomado, o presente e o passado precisam ser reconciliados. É preciso que se retome o eterno Devir das coisas, e se o ciclo foi interrompido é porque Édipo, ao matar o passado, parou o tempo, caiu na eterna Atemporalidade, colocou-se na posição de Zeus. Observemos que Zeus, ao ser posto como aquele que abarca a multiplicidade, passa a ter o mesmo valor para Ésquilo e para Homero, que a água tem para Tales, o Noûs para Anaxágoras ou o ${ }^{\circ}$ peiron para Anaximandro. É nesse meio que está Édipo, em meio à origem de todas as coisas, num mundo supra-humano, no mundo da Epistéme, quando é evocado pelo Sa-cerdote. Édipo é o Lógos tebano, por isso, foi buscado.

Diz o texto: "Édipo abandona agora o palácio e vai descendo vagarosamente as escadarias..." (p.115 Édipo Antigo), as quais simbolizam (dic. Simb. pág. 378) a ligação entre os Céus e a Terra. Como um deus foi evocado, e de seu palácio sai para o mundo da corrupção, consoante suas próprias palavras: Sucede que em toda a cidade exalam aromas odoríferos e se ouvem preces e lamentações." (p.115 idem); e a seguir temos: ".. não quis saber o que se passava pela palavra de mensageiros e eis-me aqui, para pessoalmente indagar do que está ocorrendo." Édipo não quis saber do que ocorria em Tebas através da audição e da voz, isto é, da linguagem. Desce ao mundo sensível e vem ver o que é a realidade. Assim como o personagem do Mito da Caverna (República, livro VII pp.317...), o personagem de Sófocles tem que se acostumar com a luz, tem de deixar o Mundo das Sombras e ofuscar-se com a verdade. E é nesse espaço que são marcados nitidamente os dois mundos platônicos: o Sensível e o Inteligível.

Ora, no livro VI de A República, (pp.308, 309, 310, 311-507b), lemos o seguinte:

\section{"-Que há coisas belas, e muitas coisas boas e outras da mesma espécie, que dizemosque existem e que distinguimos pela linguagem". (308)}

Édipo sabia que o relato do mensageiro não era falso, posto que a linguagem, consoante o fragmento acima, comprova a existência da coisa; mas o drama edipiano vai mais além. Já citei anteriormente que o problema é de luz. O ver dele tem que ser um ver radical, não um ver das aparências, mas o ver das essências. Ao ver, Édipo buscava a essência, visto que para Platão ( Rep. p.308) (...) postulamos que a cada uma (coisa) corresponde uma idéia, que é única e chamamo-lhe a sua essência. E se Édipo simplesmente escutasse o mensa-geiro, certamente estaria diante do inteligível, posto que estaria diante das Idéias, e estas não são visíveis. Édipo precisaria voltar à sua posição de ser em "Devir", precisava ser afetado por um terceiro elemento, haja vista que, consoan-te o livro VI (p.308 507d):

\footnotetext{
" A audição e a voz precisam de qualquer coisa de outra espécie para, respectivamente, ouvir e fazer-se ouvir, de tal modo que, se esse terceiro fator não estiver presente, a primeira não ouvirá e a segunda não será ouvida? -Não precisam de nada.
} 


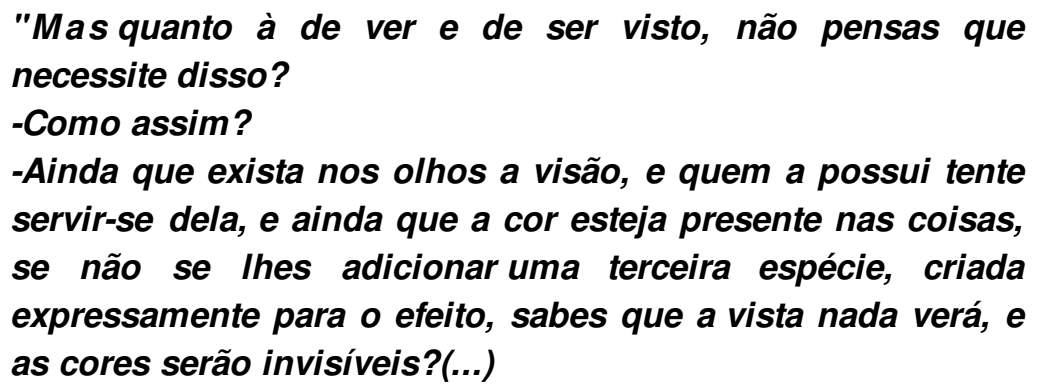

\section{-É aquilo a que chamas luz."}

Eis aí o porquê Édipo precisava ver. Pela primeira vez, não ouviu nenhum desígnio de oráculos, seus olhos foram ver, ficando estes na dependência de um terceiro elemento: a luz. A verdade não estava de forma alguma nele, no entanto, até então, ele tinha agido como sendo a Verdade tebana. Édipo, como citado anteriormente, precisava ver e ser visto, precisava de luz, precisava ser iluminado, para poder criar o seu discurso. E parafraseando aqui a professora Inês Lacerda Araújo (p.14 F>C), "Quiçá Édipo tenha o conhecimento que possa traduzir a realidade em palavras, ou seja, configu-rá-la." E é essa configuração que o Sacerdote vem requerer de nosso personagem; vem buscar o discurso, que o sensível não consegue formular, posto que dele não se pode ter um conhecimento verdadeiro. Sabe apenas que deteriora e sobre isso não possui controle; sabedor disso, dirige-se a alguém que está acima de si, que não esteja sujeito às mesmas leis do devir, mas que cause o Devir. O Sacerdote vê no corte da realidade, enquanto sempiterna, os males tebanos. A realidade enquanto aparência está sujeita a transformações, ao Devir, não pode ser parada. O Mundo Sensível é o Mundo da Corrupção, e, se Édipo ao chegar em Tebas, teve que tomar consciência disso, esqueceu-se, quando se apoderou do poder e lá permaneceu como consciente coletivo daquela cidade, de que todas as coisas são peremptórias, de que tudo está em constante mudança. O tempo parou, foi dominado pela atemporalidade; mas o mundo não é só Inteligível, é também Corrupção, por isso o cheiro exala por toda a cidade.

\section{A FORÇA DO PASSADO:}

Édipo, rei de Tebas, ou " O homem cuja natureza procede do Céu é dotado desta virtude que ele tira de si mesmo.", (-p.774- Dic. de Símbolos), síntese do Céu, do Homem e da Terra, estabelecido no centro do cosmos, é evocado por um Sacerdote ao qual ordena e permite: "Vamos ancião, fala, pois que a ti incumbe tomar a palavra, em representação destes jovens." (p.115 - Édipo Antigo).

Ao novo não é permitido falar, posto que não sofreu o processo do Devir, não possui uma ponte imediata com o eterno, com a IDÉIA, ou com a essência. O novo não possui a memória, que "...faz cruzar a história e a intimidade, o mais público e o mais pessoal, em crônicas muito originais e prenhes de contingência, crônicas do indivíduo na família, na escola, no trabalho, no bairro ou na cidade, em grupo onde os homens se nutriram simbolicamente e onde empenharam, não sem contradições, aquilo que eles nutriram..." Por isso o Sacerdote, a figura do ancião. Tebas estava dominada pelo novo, era necessária uma ponte com o passado. Era necessária a memória que revive o passado, esse passado que precisa ser revisto, mas que só pode ser revisto através da "... memória que desem-penham os velhos, tarefa para a qual estão maduros: tranqüilizar as águas revoltas do presente pelo alargamento de suas margens." (p.96 - O Olhar - anterior p. 97) E as águas revol-tas do presente tebano somente poderiam ser pacificadas se fossem alargadas as suas margens pelo passado. A memória aqui se transforma em olhar e trabalho, o que importa é "olhar em direção ao passado, olhar desgarrado com que às vezes, os velhos olham sem ver, buscando amparo em coisas distantes e ausentes." (p.97 - O Olhar), e isso o jovem era incapaz de fazer, visto que, dada a sua presentividade, ainda não possuía história, para vasculhar 0 passado e alargar o presente. O único que podia resgatar a história de Édipo era o velho, por isso aquele o respeita e o escuta.

Se analisarmos essa visão pela ótica cíclica grega, podemos afirmar que o novo ainda não está próximo do elemento de atração e criação. Além disso, (Rep. Livro I p. 5 29d) no diálogo entre Céfalo e Sócrates, este diz: " Quando as paixões cessam de nos repuxar e nos largam, acontece exa-tamente o que Sófocles disse: somos libertos de uma hoste de déspotas furiosos. " 
"E essa pessoa - ou devido à debilidade da velhice, ou
porque avista mais claramente as coisas do além, como
quem está mais perto delas (...) " p.8)

A permissão dada ao velho para falar, e não aos jovens, repousa na visão de que o velho já consegue visua-lizar o Mundo Inteligível; já seus sentidos deixaram de ser afetados pela paixão e pelo mundo do Devir. O ancião está mais perto do Mundo das Idéias. Para o ancião era mais fácil pers-crutar a alma de Édipo, posto que este representava o centro, donde a ordem ou a desordem do caos emana, na condição de rei. Eis por que a ele vai o ancião e o povo tebano; e eis por que ele imperioso diz: "Estou decidido a socorrer-vos..." como que fosse ele a medida de tudo, e tudo estivesse ao seu alcance. (p.115 ER)

\title{
O COMPROMISSO DE ÉDIPO COM A VERDADE
}

\begin{abstract}
"Eu, que agora o poder detenho que dele foi: que durmo na sua cama, e fecundo a mulher que foi sua e lhe devia dar filhos, se a sua má fortuna não tivesse caído sobre a cabeça dela; por todas essas razões, eu, como se de meu pró-prio pai se tratasse, por ele lutarei e tão longe quanto me for possível chegarei, tentando deitar mão ao responsável pela morte do filho de Lábdaco, da linhagem de Polídero e mais longinquamente de Cadmo e, antes ainda, de Agenor."

(p.121)
\end{abstract}

Édipo tem consciência de que ele tem o poder doutro. É o que é ter poder? É ter potência para... Édipo é um ser em potência mas não realizada. Ele assumiu uma posição que não Ihe pertencia, ocupa a potência de, sem no entanto ter consciência do espaço de poder que ele ocupa. Não tendo essa consciência, não pode exercer a sua potência de ser em Devir, ser que se faz. Assim sendo, envia novamente um emissário, conforme o próprio texto, para buscar o remédio para Tebas: "O único remédio que se me afigura poder ser usado, depois de ter meditado muito, já o pus em prática; ao filho de Meneceu, a Creonte, meu próprio cunhado, mandei-o ao oráculo de Febo, para por ele ser informado acerca da forma com que, por obras ou palavras, se pode a nossa cidade salvar." (p.116 - ER)

Pelo discurso anterior de Édipo podemos notar que o mesmo ainda está no círculo vicioso de buscar saber as coi-sas metafisicamente. A solução para os problemas tebanos tem se repetido sempre pela manifestação de potências extra-humanas. Édipo não tem consciência de que o homem deve atuar como um demiurgo de sua própria vida " à semelhança do demiur-go que, no Timeu, constrói o cosmos; olhos postos no modelo das idéias, entre as quais, soberana, brilha a medida - a justa medida do Bem." (p. 117 O DESEJO - A água e o Mel - José Américo Mota Pessanha). Novamente ele envia um emissário, ao Oráculo, "ao filho de Meneceu, a Creonte,..." , sem perceber, no entanto, que evocara a tradição do mensageiro. A-quele que ouviria, ou seja, teria a significação do mundo através da audição e a revelaria aos tebanos através das pa-lavras, sem o auxílio do terceiro elemento, era uma pessoa confiável. Era alguém que existia, e sua existência se dava enquanto tradição, enquanto continuidade; no entanto, Édipo não via o que falava. Evocara a tradição, mas não parecia sa-ber que " Quem é desenraizado desenraíza. Quem é enraizado não desenraíza." (Olhar e Memória - José Moura Gonçalves Filho. - p. 95 - O Olhar). Édipo não tinha essa consciência, posto que não possuía raízes; sua história era falsa, não era extensão do fio de Ariadne, não era a continuação de nada. O que se sabe dele é que "um deus te pôs no nosso caminho para endirei-tares a nossa vida.", isso pelaboca do sacerdote. (p. $116 \mathrm{ER}$ ). Mas se Tebas não sabe quem é o seu rei, tampouco o rei sabe de si. É preciso que a realidade se manifeste, que a se ponha tal qual é. E Édipo compromete-se de tal forma com a manifestação dela que diz: "Quando voltar com a resposta, acaso eu não faça tudo quanto o deus ditar, podereis, então sim, atribuir-me todas as culpas." (p.117) Nem mesmo a si ele pou-pará quando vier do Inteligível a resposta, o discurso que não consegue formular, mesmo tendo olhos para ver.

Chega Creonte. Mas "O deus de quem é o oráculo de Delfos não diz nem oculta nada: significa.", (Fr. 93 Heráclito - Hermann Diels - Ópera dos Mortos - Autram Dourado p. VII) haja vista que o Inteligível não diz - é. Ele tem que ser con-templado, precisa ser objeto de "contemplatio", para que se atinja a verdade; logo, não disse a Édipo o que ocorreu e o que estava a ocorrer, disse apenas que era preciso vingar a morte de Laios. Era preciso resgatar o passado. Este não podia ser esquecido. 
Mas o crime ocorreu quando ainda o reinado era do passado. E Édipo pergunta: "Como encontrar, hoje, o perdido rastro de tão antiga culpa?(p.118) Isto é, como extrair a Verdade no Devir. E mais a seguir Creonte fala: " Morreram todos, excepto um, que fugiu, apavorado, e apenas pôde afirmar uma coisa do que se passara." (p.118) Tudo está imerso no passado, tudo sofreu o processo de Corrupção, nada mais pode ser resgatado.

Porém, os fatos não ocorrem de forma estanque, temporalizados; um fato não se esgota no tempo e lá fica i-nerte. O passado sempre lança o seu fio para o presente. Ariadne se manifesta em todas as coisas. Tudo está repleto de Ser, mesmo o mais afastado dos seres é possuidor de menos-ser mas jamais totalmente extinto de SER; e esse menos-ser, esse fio de Ariadne, que se estende para o presente, revela-se na fala de Creonte: "Excepto um, que fugiu, apavorado ..." (p.118ER) E Édipo diz: "Ir em socorro de Laio, é ir simultane-amente em minha própria defesa." Ao defendermos o passado, automaticamente justificamos o presente. Este, por si só não se justifica. Eis por que Édipo tem um compromisso com a Verdade. Não porque se sinta acusado duma morte, mas porquanto a sua existência, a sua potência para..., somente far-se-ia a partir do momento em que ele revelasse, isto é, tirasse o véu, o qual encobria a sua história e se visse, passando a ser o demiurgo de sua própria história; mas, para tanto, era preciso conhecero passado, porque "um homem não sabe o que ele é se não for capaz de sair das determinações atuais." (p.97 Olhar e memória - José Moura Gonçalves Filho- O Olhar) A problemática aqui posta por Sófocles nada é senão o " Conhece-te a ti mesmo." o que na Grécia antiga significava Sabe que és mortal, sabe que não és um deus" (p. 02 Fogo Grego, Oliver Taplin). Essa é a consciência que Édipo não possui. A consciência de sua história e de sua humanidade. Está desenraizado, sem história. Sua história é falsa, não há nele rastros de Mnemósina, que torne o seu olhar, um " olhar desgarrado com que, às vezes, os velhos olham sem ver, buscando amparo em coisas dis-tantes e ausentes. (Idem J.Mourqa p. 97) Não possui um " Olhar fugidio mas que é paradoxalmente estilo dum ofício inserido no presente: o velho recolhe imagens de outrora, mas reclamadas nas nervuras de uma vida em ato: "relembrar exige um espírito desperto, a capacidade de não confundir a vida atual com a que passou, de reconhecer as lembranças e opô-las às imagens de agora" . Não tendo essa história, não pôde curvar e olhar com olhar fugidio, tampouco mergulhar em seu passado e descobrir os males que the assolavam no presente.

\section{O OLHAR DE TIRÉSIAS: O MUNDO INTELIGÍVEL.}

Impossibilitado de saber a Verdade, Édipo é comunicado sobre um ancião, que vê. Diz o Corifeu (p.122ER):" Conheço uma pessoa que vê tudo com mais clareza que o senhor Febo. Tal é Tirésias."

O que nos intriga aqui é como pode um homem ver melhor que um deus!... A conclusão a que podemos chegar, mais plausível, é que " o mais ser" não pode afetar o " menos-ser". Resulta da conclusão anterior que a Verdade não pode ser per-cebida de cima para baixo, mas ao contrário, somente através da ascese: de baixo para cima. Tirésias vê, porquanto con-templa o mundo a partir da visão da mente, numa atitude de demiurgo que contempla as Idéias, de forma atemporal. Na condição de ser dialético platônico, contempla a Verdade; já o deus não olha para si mesmo, mas para o mundo da corrupção, por isso reflete apenas as imagens da realidade sensível, como num espelho. A atitude é totalmente oposta. Tirésias, ao viver cego para o mundo sensível, mergulha na atemporalidade, na contemplação da Verdade. Seus olhos já não mais viam o presen-te; antes sim, a Totalidade.

Com a entrada dele em cena, dá-se o conflito maior entre os dois mundos: Inteligível e Sensível. E para tanto forma-se o seguinte palco:

\section{"Entra Tirésias, velho e cego, conduzido por um moço, entre dois servidores de Édipo." (p.121).}

Novamente algumas imagens são resgatadas: a do velho e a do jovem; mas não mais nos ateremos nesses símbolos, já os abordamos minuciosamente no capítulo III, A Força do Passado.

Sigamos a nossa caminhada, a qual seria mais árdua e longa caso se tratasse duma tese de mestrado. Tomemos, pois, a fala de Édipo ao se dirigir ao velho. Notemos com que Certeza ele fala sobre a potência de Tirésias. 
Édipo separa os dois mundos e diz deles que Tirésias tanto sabe como pode transmitir - até mesmo o inefável. Mas aquele erra; busca novamente fórmulas de escape para conhecer a Verdade. Tirésias sabe, no entanto, que Édipo tem que ser ofuscado pela luz, tem que ser iluminado, habituar-se a ela até que aos poucos consiga separar o Mundo das Sombras do Mundo da Realidade. Caso Tirésias lhe dissesse qual era o mal tebano, ocorreria o mesmo que aconteceu com o nosso personagem do Mito da Caverna (Rep. Livro VII - Platão).

Aqui reside a riqueza dessa obra. Sófocles antecipa Platão; vê através da dramaturgia aquilo que a Filosofia somente a posteriori conseguirá explicar. Mas retornemos ao conflito em que é posto o nosso vidente.

\section{"Ai! Ai! Quão terrí-vel é conhecer alguma coisa que nada pode ajudar quem a conhece! Eu já sabia isto, e contudo tentei esquecê-lo, pois de outro modo não teria aqui vindo." (p.123 ER)}

Tal qual o personagem do Mito da Caverna, Tirésias volta, mas sabe de antemão qual seria o seu fim caso dissesse a Verdade, tanto que mais adiante, no debate entre ele e Édipo, cita:

\section{" Não quero molestar-me... nem molestar-te. Por que insistes em vão? De mim nada terás." (p.123)}

"De mim nada terás." Novamente os oráculos se re-cusam a manifestar a Verdade. Édipo se recusa a ver. Se até mesmo o demiurgo viu, contemplou, quem é Édipo para querer ver sem ser ofuscado, sem sofrer o processo dialético?! Ele precisa sair do mundo das sombras, do mundo da Doxa; a "Epistéme" não se atinge sem "Contemplatio". Segundo Heráclito "La naturaleza gusta de ocultar-se" ( p. 24 fr. 56 Los Filósofos Antiguos - C. Fernandes). É preciso que o sujeito do conheci-mento se aplique à tarefa do saber que consoante Tirésias "... a verdade, embora a encubra eu com meu silêncio, a seu tempo chegará." (p.124), isto é, " adaequatio intellectus et rei". Ela não é algo que se adquira com a força, ou quando bem se pretende; há o tempo, o ciclo grego que tem que ser cumprido, condição essa que Édipo insiste em não respeitar, o que po-demos observar em sua resposta a Tirésias: " Se pensas que ela virá, por que não ma revelas agora?" (p.124-ER)

Notemos que se o ancião revelasse, tirasse o véu, manifestasse a verdade a Édipo, já não mais seria verdade, posto que estaria a faltar o terceiro elemento, mais uma vez o conhecimento estaria chegando àquele através da audição e da voz.

Mas a luta entre Doxa e Epistéme permanece. Diz Édipo ao velho: "Pensas que consentirei que me continues a falar nesse tom? (p.125); responde-Ihe Tirésias: "Sim, se a verdade possui alguma força." A verdade aqui é o poder ao qual o próprio poder deve curvar-se; mas ao ver-se atacado, destronado, Édipo busca cegar seu adversário: "Tem-na, exceto de ti; e para ti não tem, por seres cego dos olhos, como estás sendo dos ouvidos e da cabeça." (p.125)

Édipo confunde, aqui, o que é verdadeiramente estar na sombra. Não é cego quem não vê: "..."No meu modo de pensar", é cego quem não pode pensar - saber, " mesmo um pou-quinho só". Conhecer é clarear a vista, como se o saber per-mitisse, enfim, olhar. (...)" (O Olhar p. 39 - Janela da Alma, Espelho do Mundo - Marilena Chauí)., cego é aquele que vive no mundo das aparências, da opinião, que desconhece, ignora. Mas Édipo não compreende isso e novamente afronta o ancião: " Alimentas-te da noite, por isso, não poderás prejudicar, nem a mim, nem aos que vêem a luz." (p.126) , porém, novamente ele se engana, posto que consoante Chaui (p. 40 idem) "É essa imaterialidade da operação visual que a torna tão propícia ao espírito. Ela prepara os olhos para a transferência ao intelecto, começando por usurpá-los - o pensamento fala com a linguagem do olhar - e terminando por serem usurpados por ele - o espírito dirá que os olhos não sabem ver." O pensamento usurpou na Filosofia o olhar. Desde o nascimento desta, ainda consoante Chaui, (p.40) " (...), no afã de decifrar o enigma do olhar, a filosofia cindiu o que nossa atitude fideísta man-tém unido: a crença na simultânea passividade e atividade da visão. Doravante, ou a visão depende das coisas (que são cau-sas ativas do ver), ou depende de nossos olhos (que fazem as coisas serem vistas)". Além disso, o seu equívoco se dá também quanto à concepção da Noite. Não nos 
esqueçamos de que esta é prenhe de vida, (Histórias das Idéias e Crenças Religiosas vol I p. 230) além de ter sido para ela que Zeus foi perguntar "como organizar o cosmos, para que se tenha um todo com par-tes distintas?" A noite, antes de ser um obstáculo para o conhecimento, também encerra em si 0 saber. Logo, surge-nos a dúvida: quem está na Lethé ou na Alethéia?

Édipo não quer ver e formular o discurso, esquece-se de que a visão depende de nossos olhos, e de que " (p.40 idem Chaui) Entre todos os instrumentos [que servem para a alma prever] os deuses modelaram primeiro os olhos portado-res de luz e os implantaram no rosto pela seguinte razão. Um fogo tendo a propriedade de não queimar e sim de brilhar com doce luz, decidiram que seria o corpo próprio de cada dia. Porque o puro fogo dentro de nós é parente daquele, fizeram com que escoassem através dos olhos, ... )". Não conseguindo entender que ele possuía em si essa qualidade de ver, atribui aTirésias e a Creonte uma trama contra o poder, criada pela ambição humana. Se assim não fosse pergunta a Tirésias: "Por que não informaste o povo, quando aqui estava a cadela, com as suas cantigas, indicando-lhes a forma como dela se liberta-rem?".(p.126-ER) Não compreende que ao Inteligível não cabe dizer sobre a existência, mas sobre a essência. E esse, na forma de Tirésias diz: " ... tu tens na verdade olhos, mas não vês...", e a seguir: " Por agora teus olhos vêem a luz, mas em breve só verás sombras." (127) Isto é, Tirésias vati-cina o que ocorrerá com Édipo. Assim como ele, verá, e ao ver cegar-se-á como sentença por ter olhos e mesmo assim não ter visto. Assim como o vidente, verá com o olhar da Mente, não mais será afetado pelas coisas. Essa abarcará os olhos.

\section{O CONFRONTO ENTRE PASSADO E PRESENTE: LAIOS - ÉDIPO.}

Após revoltar-se contra Creonte, Édipo explica a Jocasta o porquê de sua decisão de bani-lo de Tebas. Para ele, como vimos anteriormente, Creonte tramara tudo com Tirésias para destroná-lo, fazendo com que perdesse a posição de inconsciente coletivo do povo tebano.

Jocasta, na tentativa de retirar de Édipo qualquer culpa da morte de Laios, começa a revelar-Ihe o passado. Turba-se, no entanto, o nosso personagem, quando sua esposa começa a lhe resgatar a memória. "Que profunda turbação trouxeram ao meu espírito as tuas palavras!" Que inquietação apoderouse de mim." (p.137 ER).

Ao resgatar o passado, ao seguir o fio de Ariadne, Édipo começa a sair do labirinto e seus olhos começam a ver. Notemos que Jocasta diz: "O que é que te inquietou, no que eu disse? É necessário olhar, agora, para o passado?" (p.137).

Resta-nos saber com que olhos é que se olha o pas-sado e em que lugar está depositado para que se possa vê-lo. Que olhar é esse que é capaz de estar acima do próprio tempo a ponto de colocar presente e passado frente a frente. Vejamos o que nos tem Parmênides a dizer em seu (Fr. I, 33-37 Diels): "Afasta o teu pensamento desta via de investigação e não te faças impelir sobre ela pelo costume de deixar-te guiar por um OLHO QUE NÃO VÊ, por um ouvido que retumba e pela palavra: julga porém com a Razão." (Dic. Abbagnano, p. 792).

Eis com que olhos agora vêem Édipo. Não vê o pas-sado com os olhos, posto que este é um fogo que só clareia o presente; o seu ver é o resultado não do senso comum como nos cita Heráclito: "É preciso seguir o que é universal, isto é: comum a todos; e somente a Razão é comum; (...) " (Fr. 2 Diels Abbagno p. 792). Édipo, agora, não está mais no âmbito da particularidade, mas lida com dados da Mente; bebe agora da fonte de Mnemósina; trabalha com dados universais. As conclusões a que chega não ficam no âmbito apenas da particularida-de, mas suas conclusões são comuns a todo o povo tebano.

Quanto mais adensa o diálogo entre Édipo e Jocasta, mais aquele se vê ofuscado pelo brilho da Verdade, haja vista que percebeu que vivia no mundo das sombras. Começa a sair da Caverna, de seu sensocomum, do mundo das aparências e a enfrentar a realidade. E essa constatação o leva a dizer a Jocasta: "Terrível desânimo se apodera de mim, ao pensar que o adivinho vê CLARO." (p. 138 ER). Ei-lo a notar que vivia na Lethé e não Tirésias. Aos poucos a realidade começa a configurar-se, a tomar forma, mas a Luz que desvela a Verdade não the permitira ainda associar o que via, quando habitava o mundo das sombras, à realidade. É somente com a chegada do mensageiro a anunciar a morte de seu pai adotivo Pólibo, de Corinto, que Édipo percebeu que andou em círculo. Ao invés de ir adiante, retornou; e ao 
retornar chocou-se com o passado. Na luta deste com o presente, obviamente sobrevive este.

Édipo estava desenraizado, participava dum inconsciente coletivo que não era seu, e ao tentar fugir dele, cum-pre o que o Oráculo vaticinara. $O$ presente, ao invés de caminhar para frente completando o seu ciclo, na pessoa de Édipo, para tornar-se passado, retornou e rompeu o fio de Ariadne.

Everaldo P.G. Rocha (O que é Mito, Brasiliense pp. 205, 206) cita-nos que: " Essa estranha cadeia fatal é, no fundo, a marca da tragédia para a antiga Grécia. Homens, como deuses da dor, lutando inutilmente contra desígnios de deuses que, como homens sem dor, forjam destinos em que ambos - homens e deuses - se revezam implacavelmente. Em outras pala-vras, na tragédia de Édipo, o antagonismo entre ordem divina e a ordem humana está principalmente expressa na idéia de que os homens são sujeitos de suas vontades, mas o que estas vontades realizam concretamente são as vontades dos deuses e não as dos homens. No limite, vemos que os homens fazem o que querem, contanto que este querer seja o dos deuses. " (p. 205 -206). Mais a seguir o mesmo autor no cita: " Quando penso que estou fazendo minha vontade, estou, de fato, cumprindo a vontade alheia. A vontade dos deuses. Um jogo de vontades com cartas marcadas, sem apelação ou escapatória." (Idem p. 206).

Ora, se tudo está no mundo das Idéias, Apolo nada vaticinou. Quando consultado, simplesmente, significou, isto é, deu signos tanto a Laios quanto a Édipo, signos estes utilizados pelo demiurgo para criar - Mundo Sensível. O Oráculo nada vaticinara, apenas dissera a ambos que o Mundo Sensível está em constante mudança. Não houve uma imposição dos deuses, antes sim, uma manifestação da realidade tal qual é, posto que lhes foram relevados, simplesmente o ser das coisas.

Laios, ao saber que seria destronado, tenta evitar isso. Não admitia perder a posição de eterno presente de Te-bas. E o que o Oráculo lhe revelara era que ele um dia seria substituído pelo seu filho. Mas ele não aceita passar o trono, transformar-se em passado, não aceita o Devir, o que é natural no Mundo Sensível. Esqueceu-se de que o passado não podia ma-tar o presente, no máximo feri-lo deixando a sua marca. Em momento algum, ambos estavam sob a determinação ou a vontade dos deuses, antes sim, sob a determinação do eterno Devir das coisas, ao qual Laios não quis subordinar-se.

\section{O RESGATE DO CICLO GREGO: JOCASTA.}

Édipo, agora, está diante do passado, este desvela quem Édipo é. Cumpre-se o árduo "Conhece-te a ti mesmo" . Nosso personagem vê, através da figura dos anciãos. É chamado o "boieiro" o qual comprova a descendência de Édipo. Jocasta sai apressada e entra no palácio. Um mensageiro sai do palácio e comunica: "Só duas palavras. Num momento se dizem, num mo-mento se escutam: a nobre Jocasta está morta." (p.156 ER). A seguir, ainda na fala do mensageiro, ao se referir ao desespe-ro em que se encontrava Édipo em busca de sua mãe e mulher diz-nos: "... pedia-nos uma arma, , queria que lhe disséssemos onde estava a sua mulher; não sua mulher, mas aquela dupla mãe onde se geraram ele e os seus filhos." (p. 156-ER)..

Tebas havia perdido os laços com o passado; nela existia apenas o eterno presente; o ciclo grego precisava ser retomado, e somente uma pessoa poderia retomá-lo: Jocasta. Ela era a única ponte que Édipo tinha com o passado, por isso "aquela dupla mãe". Eis por que não ocorre para os gregos a questão do incesto. Caso Édipo se unisse a alguém do presente, seria a consolidação da eterna presentividade. Somente Jocasta possuía o ventre que resgataria o ciclo do eterno Devir. O presente, portanto, se une ao passado e retoma o fio de Ariadne, na figura dos filhos de Jocasta e Édipo.

Observemos que na fala do mensageiro temos: "A nobre Jocasta está morta." Em momento algum pesa sobre ela, por parte dos tebanos, um crime de incesto; isso porquanto a figura da mãe, para os gregos, é o da "Magna Mater". A mu-lher, consoante Duby e Perrot, "imita a terra" no ato da reprodução. (p. 49 História das Mulheres na Antiguidade -). Já num segundo momento temos, também, pela fala do mensageiro, Jocasta sendo dada como " ... aquela dupla mãe onde se geraram ele e os seus filhos". Cabe-nos ver nesta fala duas coisas importantes. A primeira é que Jocasta é vista como dupla mãe. Isso se dá posto que ela pariu o presente, na figura de Édipo, transformando-se no inconsciente coletivo do povo tebano e posteriormente resgatando o ciclo através dos filhos que tem com Édipo. Já a segunda coisa a ser observada, é o advérbio de lugar utilizado para designá-la: "onde". Jocasta deixa de ser uma pessoa e transforma-se num lugar; isso ocorre porque a mãe é vista como a Grande Gê, ou seja, a Mãe- 
Terra. Não nos esque-çamos também de que, para os Gregos, consoante Duby e Perrot, (p.50) "... a mãe existe. Os gregos a veneram." A mãe para eles é como uma deusa, ela "... é tudo (ou o todo) ... a Idéia reguladora de tudo. Neste aspecto ela garante perfeitamente a origem, porque ela é a origem." (p.53 - Hist. das Mulheres) Portanto, a única pessoa que poderia novamente originar o ciclo grego era Jocasta. Somente ela possuía essa ponte com a Totalidade. Notemos, pois, que o texto cita-nos que a mãe é a Origem e que também é Idéia. Se era Idéia e Origem, logo, ela era a essência de todas as coisas. Jocasta representava o princípio gerador de todas as coisas, portanto, encerrava em si, a Totalidade. Ela era a Grande Gê que estava por detrás de todo DEVIR.

Assim podemos vê-la, posto que Severino nos cita que "Nos primeiros pensadores gregos, a evocação do sentido inaudito da Verdade é também (e não podia deixar de ser) um dirigir-se à Totalidade das coisas..." (p.20 -A Filosofia Antiga -Severino) Se a busca da Verdade é, também esse dirigir-se para a Totalidade, Édipo só descobre aquela ao deparar-se com a mãe; isto é, com aquela que abarcou tanto o seu presente quanto o seu passado. Ela continha em si a Verdade, posto que nela estava a possibilidade de retomada do ciclo grego, bem como nela também estava a própria essência do que era Édipo.

\section{A "INTELIGIBILIDADE" : CEGUEIRA DE ÉDIPO.}

"Agora vereis, nas trevas, os que nunca devíeis ter visto: e também os que ansiastes conhecer." (p. 157 ER)

A o presenciar a terrível cena de Jocasta, enforcada, diz-nos o mensageiro que Édipo " ... retira os alfinetes de ouro com que, como adorno, ela segurava os vestidos, empunha-os e vai cravá-los nas órbitas, gritando que o fazia para a não ver a ela, nem aos males de que sofria, nem ainda aos que ele mesmo povoou." Ao abrirmos o Dicionário de Símbolos (p. 434 - Cirlot) temos: "O ouro é a imagem da luz solar e, por conseguinte, da inteligência divina." Fora afetado pelo "Pháos" recebera o dom dos deuses. Contemplara a "Totalidade, e ao vê-la cegara-se para a Realidade Sensível; fora além desta. A Mente terminou por usurpar o olhar e, após, disse que os olhos não sabiam ver, furtando-lhe a "Luz": "Agora vereis nas Trevas..." (p.157). A partir de então passou a ver com o olhar de Tirésias; via metafisicamente, já não mais necessitava do terceiro elemento externo a si: "Pháos" . Esta fora abarcada pelo olhar da "Mente", que por si só se auto-ilumina com as "Idéias". A lembrança, a memória tornou-se a única coisa visível para Édipo: "Ai de mim, e de novo, ai de mim! Como se crava, em mim, o aguilhão da lembrança dos meus males!." (p.,158 -ER). Agora Édipo vê com os olhos desgarrados dos ve-lhos. Não possui olhos, mas vê, uma vez que seu olhar apoia-se em modelos pré-existentes e eternos. Édipo, a partir de então, participa do "Mundo das Idéias", contempla a "Tota-lidade", não mais o que o "lumem" Ihe permite ver num presen-te. Transforma-se em Atemporalidade, haja vista que a "Mente" é capaz de mergulhar no tempo, sem a este estar sujeita. Édipo agora conhece posto que conhece. Cita-nos Mircea (p. 170 - História das Idéias) VollII) que "Para Platão, conhecer equi-vale, em última análise, a lembrarse." Se assim o é, Édipo lembrou-se, bebeu do Lago de Mnemósina. Sua vida não é mais um caos, transformou-se em um "Kósmos", (Conjunto das coisas que saíram da desordem ou do Cháos)* (p. 21 Severino)

O ciclo metafísico foi cumprido. Édipo chegou ao Inteligível, sofreu o processo de ascese, não mais porque os deuses vaticinaram. Da mesma forma que adivinhara o segredo da "Esfinge", assumindo-se enquanto ser em Devir, ao responder que era "O Homem"; precisava Saber e saber-se, e o conhecimento somente se dá quando o homem olha de dentro para fora e não ao contrário. Édipo, não mais recebeu a Verdade" a partir dum oráculo, essa se construiu a partir da Memória resgatada.

No capítulo "Os Labdácidas: o Mito de Édipo.", (p.269 - vol. III Mitologia Grega) Junito ratifica os argumentos anteriormente desenvolvidos neste trabalho, no capítulo VIII. " Do ponto de vista simbólico, todavia, a cegueira que Édipo se infligiu possui um sentido mais profundo. As trevas externas geram a luz interna. A (anagnórisis) " ação de reconhecer" e de reconhecer-se começa efetivamente a existir quando se deixa de olhar de fora para dentro e se adquire a visão de dentro para fora. Mergulhado externamente nas trevas, o herói se encontrou. Se Édipo, porque sabia, conquistou o poder, a hipertrofia desse mesmo poder sufocou-lhe o saber. Sua cegueira estabeleceu em definitivo a ruptura entre o saber e o poder: cego, o herói agora sabe, mas não pode." 
Édipo perdeu o poder em Tebas, mas ganhou o saber. Sai da condição de poder Temporal para Atemporal. Reconhece a si e a Tebas. Não está mais desenraizado. A história de Tebas cumpriu o ciclo de crescimento: sofreu o ritual de passagem. De Cadmo a Édipo, a história de Tebas foi a história da fuga, e de apropriação indébita do poder. Tebas foi sempre comandada por reis que podiam mas não sabiam. " Cego, o herói agora sabe (formulou o seu discurso), mas não pode." (p. 269 - Juni-to - Vol. III - Já citado)

\section{CONCLUSÃO}

"Qual o animal que, possuindo voz, anda, pela manhã, em quatro

pés, ao meio-dia, com dois e, à tarde, com três?"

(Junito p. 261 - V. III - Mitol. Grega)

Severino, em sua obra (p. 19 - A Filosofia Antiga) cita-nos que "O mito não pretende ser uma invenção fantástica, mas sim a revelação do sentido essencial e total do mundo." Ora, o que vimos até então foi Sófocles, através de Édipo-Rei, buscar a essência do mundo tebano através do "Mythos", isto é, por intermédio da palavra. Esta é reveladora da "RES em si" , ou seja, da essência da realidade, ou da manifestação da Idéia; por isso Édipo teria que construir o seudiscurso. Este the não foi dado nem pelo cego Tirésias, nem pelo Oráculo. Da mesma forma que ele decifrou o enigma da Esfinge, teria que por si só formular o discurso, identificando-se, e a Tebas.

Não podemos negar que em Édipo-Rei ainda não temos um pensamento epistêmico, mas é inegável que a busca do "Sa-ber" (Sophia), do "Lógos (Razão), da "Alethéia" (Verdade) já se configura nessa peça.

Por outro lado, se "Philosophia" significa "o interesse pelo saber" (p. 20 - Severino vol 1) e se "Sophia" ecoa tal como o adjetivo Saphés (claro, manifesto, evidente, verdadeiro) e se o sentido de pháos é luz, então filosofia significa o interesse por aquilo que se encontra sob a luz. (Apud p. 20 - Severino); e, se Édipo tem que ser iluminado, tem que buscar a Verdade, ele tem que se portar como um filósofo. Tem que buscar aquilo que está sob a luz, aquilo que é verdadeiro, que se manifesta. A partir desse pressuposto podemos dizer que a obra Édipo-Rei não se limita apenas a uma recriação da realidade, como vê Platão a obra literária, mas nela Sófocles já ensaia uma problemática maior, que é a busca do Verdade; problemática essa que é um discurso de sua época.

Sófocles, ao buscar a essência da realidade, através de seu personagem, centra a atenção nas idéias que fecun-dam a sua época. Notemos, pois, que nosso dramaturgo nasceu em Colono, cerca de 495 a.C; já Heráclito em 549? - 475?, enquan-to Parmênides 515/510? -435. Sófocles viveu exatamente no período em que as teorias de ambos os filósofos foram expostas, e delas ele se apropria para levar Édipo a sair da obscuridade, centrando sua atenção em dois mundos: o dos olhos que pos-suem luz, mas não vêem, e o dos olhos que não possuem luz mas vêem. O primeiro mundo apresenta uma realidade que está em constante movimento, como nos comprova o fragmento 61 de Plu-tarco "No se puede entrar dos veces en el mismo rio - según Heráclito -, ni tocar dos veces la misma sustancia mortal según su manera de ser; sino que, por la intensidad y rapidez de su cambio, se dispersa y se recoge de nuevo, se acerca y aleja." (p. 23 - Los Filósofos Antiguos). por isso os olhos não conseguem reter a essência da realidade, mesmo havendo luz, visto que se as coisas não são sempre as mesmas, é impossível se obter conhecimento verdadeiro face à sua constante mudança.

Já o segundo mundo é o de Parmênides (p. 28 - F. Antiguo) manifestado no fr. 8 "Ya no nos queda más que um relato posible, el de la vía de que "es". A lo largo de esta via hay numerosísimas señales: que el ente es ingénito e in-destructible, entero, unigénere, inmoble y perfecto. Ni "fue" jamás, ni "será", puesto que "es" ahora todo junto, uno y con-tinuo (v.1-6)" , ou seja, é o mundo imobilidade, não criado, que não é suscetível de mudanças. Desse mundo é possível o conhecimento, e foi nele que Édipo foi buscar o a sua histó-ria, o conhecimento de seu passado, a sua essência. Esses mundos, os quais estão em jogo na peça de Sófocles, foram posteriormente conciliados por Platão (429/427 -348/347), em Mundo Sensível e Mundo Inteligível, respectivamente.

Sófocles utiliza-se do Mito, mas para deste fugir. Notemos que a condição " Sine qua nom" para que Édipo seja iluminado, é que ele "Veja", parta da contemplação da realidade e vislumbre, isto é, que o pensamento atravesse, sem se distrair, a infinita riqueza das coisas, dirija-se ao Todo, que percorra 0 confim extremo, para lá do qual nada existe e consiga vislumbrar a reunião em conjunto das coisas mais diferentes e mais antitéticas, a sua reunião numa suprema uni-dade. $\left(^{*}\right)$ (Apud - Severino pp. 21,22). Mas isso só poderia ocorrer a partir do momento em que Édipo praticasse a ascese, sem a ajuda dos deuses, 
assim como ele decifrou o enigma da Esfinge. Foi essa exigência imposta pelo dramaturgo que fez com que Tirésias se calasse. Édipo tinha que transcender o Sensível para deixar de ver as coisas de forma fragmentária e abarcar a Totalidade, haja vista que ele representava a Totalidade Tebana; o mundo enquanto restringido à Tebas.

O problema edipiano é o problema da Verdade, e "A evocação do sentido inaudito da verdade implica que nos diri-jamos não a esta ou àquela dimensão particular da realidade, mas ao Todo, para questionar qual será a Verdade inegável. Apenas se nos deixarmos levar até aos extremos confins do Todo é possível que com ela nos deparemos." (p. 22 Severino.) Mas Édipo, num primeiro momento, não fez isso. Ao desvendar o enigma da Esfinge pensou que detinha a Verdade. Esta não estava no homem, tampouco nesse mundo da Corrupção, ela estava para além do homem, assim como o problema tebano estava para além de Édipo. A problemática era uterina, por isso ela parte do útero, de Delphos o qual "tinha uma préhistória como local oracular muito antes de Apolo ... os gregos ligavam-Ihe o nome a delphús, "útero". A cavidade misteriosa era uma boca, um stómios, termo que designa também a vagina. (...) Por símbolo do umbigo, estava carregado de sentido genital; mas era sobre-tudo um "Centro do Mundo".(p.247- Mireca) Por isso os personagens de Sófocles partem de Delphos e a ele sempre recorrem para obterem a Verdade. Mas o útero precisa ser fecundado, ele não se manifesta gratuitamente, da mesma forma que é preciso contemplar a realidade e transcendê-la, não ficar somente nela, haja vista que na realidade há laivos da Idéia; há Tiré-sias no Mundo. Em suma, o mundo não está totalmente desprovido de Ser, " As coisas são habitantes do Todo, não apenas no sentido, mais forte, de que a origem da qual provêm e 0 termo final que, ao partirem, atingem, estão eles próprios contidos no Todo." (p. 28 - Severino - vol. 1) Mas onde estava essa Totalidade, essa essência à qual Édipo deveria atingir? Na Mente, na Memória. Por isso ele tinha que resgatar todo o seu passado, e este, por não estar diante dos olhos sensíveis, por não estar afetado pela luz, não podia ser passível de conhecimento. Somente a Mente, atemporal e iluminada é capaz de ver além do presente.

Édipo, enfim, sai de sua Caverna, sofre o processo de habituar-se à "Lux" de Ser que é iluminado e transforma-se em "Lumen". Tanto Tebas, quanto Édipo, agora, têm seu passado, e aquela o seu inconsciente coletivo resgatado, postoque o ciclo grego fora retomado, quando da saída de Édipo do poder. A "Physis" tebana volta a ser esse eu "nasço", " sou gerado", de maneira que Tebas volta a ser 0 reino dos seres que nascem (e, portanto, morrem), ou seja, volta a ser um Mundo do Devir. (Apude p. 24 Severino)

Através da análise da obra Édipo-Rei pudemos constatar que a grandeza de Sófocles reside, exatamente, na capacidade de antecipar a conciliação platônica das teorias de Parmênides e de Heráclito; já, a virtude de Platão consiste em ter ido além de Sófocles, ao sistematizar o pensamento grego e lançar a problemática para o Mundo da Epistéme, enquanto aquele ficou no Mundo da Representação. 